"This is an original manuscript / preprint of an article published by Taylor \& Francis in: Bueno, X. and Brinton, M.C. (2019): Gender egalitarianism, perceived economic insecurity, and fertility intentions in Spain: A qualitative analysis, Population Studies, 73(2): 247-260. 17 may 2019, available online: https://doi.org/10.1080/00324728.2019.1604979

\title{
Gender Egalitarianism, Perceived Economic Insecurity, and Fertility Intentions in Spain: A Qualitative Analysis
}

\author{
Xiana Bueno ${ }^{\text {a* }}$ and Mary C. Brinton ${ }^{\mathrm{a}}$ \\ ${ }^{a}$ Department of Sociology, Harvard University, Cambridge, MA, United States
}

\begin{abstract}
Economic uncertainty has been posited as an important contributor to low fertility in many European countries. A separate line of research emphasizes the role of gender inequality in depressing post-industrial fertility. This paper examines how these two forces interact in the context of Spain, a society where young adults face tremendous economic uncertainty yet simultaneously express gender-role attitudes that are much more egalitarian than those of the prior generation. We draw on original in-depth interviews to analyse how the reasoning about fertility intentions among young highly-educated partnered urban men and women in Spain is conditioned by the combination of gender egalitarianism and perceived economic insecurity. Interviewees' narratives suggest that the positive relationship between gender egalitarianism and fertility intentions hypothesized by many social demographers is hampered by couples' challenges in dealing with the uncertain economic environment, Spain's dualistic labour market, and the low level of institutional support for dual-earner couples.
\end{abstract}

Keywords: gender egalitarianism, perceived economic insecurity, fertility intentions, Spain, qualitative analysis 
"This is an original manuscript / preprint of an article published by Taylor \& Francis in: Bueno, X. and Brinton, M.C. (2019): Gender egalitarianism, perceived economic insecurity, and fertility intentions in Spain: A qualitative analysis, Population Studies, 73(2): 247-260. 17 may 2019, available online: https://doi.org/10.1080/00324728.2019.1604979

\section{Introduction}

Very low fertility rates characterize a large number of post-industrial countries in Europe and East Asia (Kohler et al. 2002; Billari and Kohler 2004; Goldstein et al. 2009).

Economic uncertainty has been posited to be a major driver of low fertility in Europe, and an extensive literature has examined the relationship between macro-economic instability and total fertility rates (Tölke and Diewald 2003; Mills et al. 2005; Sobotka et al. 2011; Kreyenfeld et al. 2012; Vignoli et al. 2012; Örsal and Goldstein 2018). More recently, many social demographers have adopted a micro-level perspective and have analysed the relationship between economic uncertainty and fertility at the couple level (Özcan et al. 2010; Kreyenfeld et al. 2012; Testa and Basten 2014). But while the number of such studies has increased, results are often contradictory across different countries or across social groups (e.g. by educational level) in the same country (Özcan et al. 2010; Sobotka et al. 2011; Kreyenfeld et al. 2012; Raymo and Shibata 2017). Indeed, as Sobotka et al. (2011, pp. 267) point out, 'Individual fertility decisions at times of economic recession will often be differentiated by sex, age (or stage in the life cycle), ethnicity, socioeconomic status, and current family size.' Understanding the patterning of the economic insecurity-fertility relationship across social groups, including the sexes, in different countries thus remains a key agenda for social demographers studying low-fertility societies.

The negative effect of male unemployment on family formation has been generally assumed in the fertility literature for many decades. As female labour force participation has increased and a dual-earner model has become more widely accepted in many postindustrial societies, social demographers have turned their attention to the relationship 
"This is an original manuscript / preprint of an article published by Taylor \& Francis in: Bueno, X. and Brinton, M.C. (2019): Gender egalitarianism, perceived economic insecurity, and fertility intentions in Spain: A qualitative analysis, Population Studies, 73(2): 247-260. 17 may 2019, available online: https://doi.org/10.1080/00324728.2019.1604979

between women's unemployment and fertility as well (Kreyenfeld et al. 2012). Despite this addition of gender to the literature on economic uncertainty and fertility, however, little attention has been paid to how a couple's gender egalitarianism may condition the relative impact of men's and women's perceived employment insecurity on fertility plans. This paper addresses this issue in urban Spain, a context characterized by high economic uncertainty and increasingly egalitarian gender-role attitudes and behaviours. We pose three questions, one of which is descriptive and two of which are based on theoretical considerations.

First, how strongly do highly-educated partnered young adults in Spain factor the perception of economic insecurity into their reasoning behind fertility decisions? Second, is economic insecurity considered less of an obstacle to fertility among more genderegalitarian couples, given that they prioritize both men's and women's wage-earning capability and may thus consider income as less "gendered" than less egalitarian couples? Third, is gender equity theory's expectation (McDonald 2000, 2006, 2013) that more gender-egalitarian couples are likely to have higher fertility intentions borne out in a context of high economic uncertainty such as Spain? We utilize a qualitative approach, drawing on original in-depth interviews with young highly-educated partnered adults in Madrid and Barcelona to ascertain the reasoning they express for their intentions.

We consider Spain to be a highly appropriate case for our theoretical purposes. Along with Italy, Spain was the first country to have a total fertility rate below 1.3, marking it as a "lowest-low fertility" country in the early 1990s. Spain has experienced a high level of economic uncertainty since the 1980s, especially among the young working-age 
"This is an original manuscript / preprint of an article published by Taylor \& Francis in: Bueno, X. and Brinton, M.C. (2019): Gender egalitarianism, perceived economic insecurity, and fertility intentions in Spain: A qualitative analysis, Population Studies, 73(2): 247-260. 17 may 2019, available online: https://doi.org/10.1080/00324728.2019.1604979

population. Spanish unemployment rates have exceeded those in other European countries for most of the past three decades, and the economic circumstances of young Spanish adults at all education levels have been severely impacted by the restructuring of employment away from stable jobs towards short-term contract work (Adserà 2011a; Arpino and Tavares 2013). Accordingly, it is well-recognized that economic insecurity is a major driver of very low fertility rates in Spain (Ahn and Mira 2001; Simó Noguera et al. 2002; De La Rica and Iza 2005; Adserà 2011b).

At the same time, Spain is an unusual case among Southern European societies in terms of the rapid change it has experienced in gender-role attitudes and behaviours (Arpino and Tavares 2013; Sullivan et al. 2014; Arpino et al. 2015). McDonald and others (McDonald 2000, 2006, 2013; Esping-Andersen and Billari 2015; Goldscheider et al. 2015; Brinton and Lee 2016) have posited that post-industrial societies with very low fertility tend to be characterized by inegalitarian gender-role attitudes and behaviors. But Spain does not easily fit this profile. Instead, Spanish gender-role attitudes are now considerably more egalitarian than those of other very low-fertility countries such as Italy and Japan (Arpino and Tavares 2013; Brinton and Lee 2016; Knight and Brinton 2017). Arpino and Tavares (2013) found that the propensity for having a positive attitude towards gender equity in the household has increased so rapidly in Madrid, for example, that it now exceeds the mean for Europe overall. Does gender egalitarianism in Spain exert the positive effect on couples' fertility intentions assumed by gender equity theory, and is it therefore perhaps serving as a counteracting force against the pervasive climate of economic uncertainty? If the Spanish economy improves, will this burgeoning egalitarianism lead to a 
"This is an original manuscript / preprint of an article published by Taylor \& Francis in: Bueno, X. and Brinton, M.C. (2019): Gender egalitarianism, perceived economic insecurity, and fertility intentions in Spain: A qualitative analysis, Population Studies, 73(2): 247-260. 17 may 2019, available online: https://doi.org/10.1080/00324728.2019.1604979

rebound in fertility? While we cannot presume to answer these questions, we highlight them as the central concerns motivating our analysis.

\section{Gender inequality and fertility}

Gender equity theory (McDonald 2000) highlights the centrality of gender relations for post-industrial fertility change, positing that with women's increased labour market opportunities, fertility is likely to be low unless gender equity increases. McDonald predicts that in the absence of greater participation by men in housework and childcare and greater institutional support for childrearing, the dual demands placed on women by the household and labour market are likely to depress fertility. Researchers have posited a link between men's increasing participation in housework in low-fertility countries and a slight uptick in total fertility in these countries in the 2000s (Sullivan et al. 2014). At the micro-level, quantitative studies have examined the relationship between the household division of labour and fertility (see for example Oláh 2003; Cooke 2004, 2009; Torr and Short 2004; Bernhardt and Goldscheider 2006; Puur et al. 2008; Mills 2010; Nagase and Brinton 2017), and many of these studies report a positive relationship between men's contribution to household labour and fertility intentions or transition to second birth.

Does the posited relationship between fertility and gender egalitarianism exist independently of the economic environment within which couples find themselves and, more specifically, independently of couples' own perceived economic insecurity? This is a very important question for a case such as Spain, where gender egalitarian attitudes have spread rapidly but where economic uncertainty and job instability have been high. In order 
"This is an original manuscript / preprint of an article published by Taylor \& Francis in: Bueno, X. and Brinton, M.C. (2019): Gender egalitarianism, perceived economic insecurity, and fertility intentions in Spain: A qualitative analysis, Population Studies, 73(2): 247-260. 17 may 2019, available online: https://doi.org/10.1080/00324728.2019.1604979

to develop our expectations, we briefly consider the literature on economic insecurity and fertility and consider the key institutional features of the macro-level context in Spain that are relevant for fertility.

\section{Economic insecurity and fertility}

After focusing mainly on the link between men's employment and family formation, social demographers have recently examined the relationship between women's employment circumstances and fertility as well. This has become particularly important in the postindustrial world given the universal increase in women's educational attainment. Recent literature suggests that while economic insecurity among less-educated women is frequently associated with a more rapid transition to childbearing (Sobotka et al. 2011), it is often linked to childbearing postponement among highly-educated women (Schmitt 2008; Kreyenfeld 2010). Consistent with opportunity cost theory, the higher a woman's current or potential salary, the greater the likelihood that she will delay motherhood, although many women subsequently "catch up" with second and third births (Rondinelli et al. 2010).

In terms of linking together gender equity theory and the economic insecurity literature on fertility, there is a key unaddressed issue: Looking at the sex-specific link between economic insecurity and fertility, as researchers have typically done, obscures the couple-level dynamics highlighted by gender equity theory. The economic insecurity literature does not directly speak to the issue of how both partners' employment statusand the meaning men and women attribute to it-influence fertility. For instance, while it is certainly important to investigate the different effect economic insecurity may have on the fertility of less- vs. highly-educated women, this neglects the influence that gender- 
"This is an original manuscript / preprint of an article published by Taylor \& Francis in: Bueno, X. and Brinton, M.C. (2019): Gender egalitarianism, perceived economic insecurity, and fertility intentions in Spain: A qualitative analysis, Population Studies, 73(2): 247-260. 17 may 2019, available online: https://doi.org/10.1080/00324728.2019.1604979

egalitarian norms and institutions as well as couple-level egalitarianism have on fertility. As Raymo and Shibata (2017, p. 202) point out, 'The tendency either to focus on men or women separately...or to consider economic circumstances at the household level...may obscure insights about how fertility is associated differently with the employment circumstances of men and women as well as how those gender-specific relationships may be shaped by social and economic context.' For example, the finding in some countries that highly-educated women's employment prospects are relevant for fertility could be due to the importance of opportunity costs and/or also due to the fact that highly-educated couples tend to be more egalitarian and to privilege women's career and income more than lesseducated couples do.

We address these issues for the case of Spain by comparing the discourse on fertility intentions and obstacles employed by highly-educated partnered young adults who are more vs. less gender-egalitarian. We control for educational level by sampling only the highly-educated. We then consider whether a couple's egalitarianism seems to "cushion" them from feeling that economic insecurity is an obstacle to their fertility intentions, and whether they consequently have higher fertility intentions than less egalitarian couples.

Besides egalitarianism, features of the macro-level context such as labour market structure and state support for dual-earner couples also may influence how couples think about the implications of their economic insecurity and about women's job instability in particular. We turn now to these institutional forces within the context of Spanish society.

\section{Labour market structure}


"This is an original manuscript / preprint of an article published by Taylor \& Francis in: Bueno, X. and Brinton, M.C. (2019): Gender egalitarianism, perceived economic insecurity, and fertility intentions in Spain: A qualitative analysis, Population Studies, 73(2): 247-260. 17 may 2019, available online: https://doi.org/10.1080/00324728.2019.1604979

Spain is characterized by an "insider-outsider" labour market with many temporary shortterm jobs and fewer jobs with stable employment contracts (Adserà 2011a). Reforms since the mid-1980s have exacerbated this insider-outsider structure and have resulted in an expanded number of fixed-term contract jobs. Survey data show that while 90 percent of employees in Belgium, Denmark, Finland, and Ireland are not worried about losing their jobs, this applies to only 55 percent of employees in Spain (Hipp 2016). Empirical studies in Spain find a strong effect of job insecurity on family formation delays (Ahn and Mira 2001; Simó Noguera et al. 2002; De la Rica and Iza 2005), postponement of second birth, and an increased gap between desired and actual fertility (Adserà 2004, 2006, 2011a, b; Castro-Martin and Martin-Garcia 2013; Castro-Martín and Seiz 2014). Consistent with these findings, in their analysis of the realization of short-term fertility intentions in 22 European countries Harknett and Hartnett (2014) find that Spain has one of the lowest rates of correspondence between fertility intentions and achieved births three years later.

In societies with an insider-outsider labour market structure, the sex-specific effect of job insecurity on fertility prospects is likely to depend on the strength or weakness of the male-breadwinner model of the family. Japan, for instance, shares a total fertility rate very similar to Spain's and a dual (insider-outsider) labour market structure, but has a genderrole ideology that is much more supportive of a male-breadwinner model (Brinton et al. forthcoming). Raymo and Shibata (2017) find that the negative effect of economic recession on Japanese fertility after 1990 operated through young adult males' increased propensity to hold temporary jobs; they estimate that the impact of this negative effect would have been much larger had the decline in stable employment not exerted upward 
"This is an original manuscript / preprint of an article published by Taylor \& Francis in: Bueno, X. and Brinton, M.C. (2019): Gender egalitarianism, perceived economic insecurity, and fertility intentions in Spain: A qualitative analysis, Population Studies, 73(2): 247-260. 17 may 2019, available online: https://doi.org/10.1080/00324728.2019.1604979

pressure on fertility through married women's reduced prospects for "good" jobs (accentuating a substitution effect). The effect of economic insecurity on fertility may be less sex-specific in Spain, given much greater ideological support for dual-earner couples and the near taken-for-grantedness that women, especially the highly-educated, will work. Couples who are particularly egalitarian may have a higher proclivity to prioritize both the male and female partner's job stability. We propose two contrasting expectations for the relationship between perceived economic insecurity and fertility reasoning relative to couples' egalitarianism:

1a) More gender-egalitarian couples who perceive economic insecurity to be an obstacle to fertility will have higher fertility intentions than less egalitarian couples, as they will feel that the attainment of job stability for either the male or female partner will lower the economic barrier to childbearing decisions. In this way, these economically insecure egalitarian couples may approach childbearing decisions with greater confidence and flexibility than economically insecure couples who are less egalitarian. This expectation would be consistent with gender equity theory.

A contrasting expectation would be:

1b) More gender-egalitarian couples who perceive economic insecurity as an obstacle to fertility will have lower fertility intentions than less egalitarian couples, as they will prioritize the attainment of job stability for both the male and female partner before proceeding with childbearing decisions. Childbearing will be delayed until both partners become established in the labour market. At that point, the provision of two incomes may facilitate higher fertility intentions and a more rapid progression to first and second births. In this sense, egalitarianism may "cut both ways" in economically insecure situations. 
"This is an original manuscript / preprint of an article published by Taylor \& Francis in: Bueno, X. and Brinton, M.C. (2019): Gender egalitarianism, perceived economic insecurity, and fertility intentions in Spain: A qualitative analysis, Population Studies, 73(2): 247-260. 17 may 2019, available online: https://doi.org/10.1080/00324728.2019.1604979

\section{State support for dual-earner couples}

Some scholars suggest that highly-educated women's propensity to delay childbearing is related to the structure of state support such as childcare leave. In welfare states such as Sweden, for example, parental leave and the right to return to a job at the same level are guaranteed to employees with permanent contracts but not necessarily to those with temporary contracts. This can lead highly-educated women in particular to wish to delay childbearing until they secure a job with a permanent contract (Brinton et al. forthcoming). The Swedish gender-equal parental leave allowance- 80 percent of income prior to childbirth—also incentivizes men and women to obtain well-paying jobs before having children (Andersson 2008). In Spain, Adserà (2006) finds that women working in the public sector are less likely than those in the private sector to have a fertility idealsintentions gap. She traces this to the fact that women in the public sector have greater job stability and more benefits than women in the private sector, especially those in temporarycontract jobs. Moreover, parental leave policies are more universally upheld in the Spanish public sector than the private sector (Meil et al. 2008).

Under Spanish law new mothers are entitle to 16 weeks of paid maternity leave and fathers are entitled to four weeks of paid leave (two weeks at the time of our interviews in 2012). Maternity and paternity leave are supplemented by unpaid childcare leave that can be taken by the mother or the father. Childcare leave is generous in terms of length; fulltime leave can be taken until a child is three years old and part-time leave can be taken until a child is twelve years old (up to eight years old at the time of our 2012 interviews). Leave policy is not restricted to employees with permanent contracts. But because it is unpaid, 
"This is an original manuscript / preprint of an article published by Taylor \& Francis in: Bueno, X. and Brinton, M.C. (2019): Gender egalitarianism, perceived economic insecurity, and fertility intentions in Spain: A qualitative analysis, Population Studies, 73(2): 247-260. 17 may 2019, available online: https://doi.org/10.1080/00324728.2019.1604979

leave usage depends heavily on the ability of a couple to afford a temporary reduction in one or both partners' work hours. Spanish women are much more likely than men to use unpaid parental leave, with only five of every 100 leave-takers being men (Lapuerta et al. 2011). Parents' difficulties in balancing work and family, especially during children's early years (up to age three), are aggravated by a shortage of public daycare spaces. Baizán (2009) finds that regional daycare shortages in Spain are negatively related to aggregate fertility. Public spending on family-related services as a percent of GDP has been low in Spain (Adserà 2004).

In sum, Spain has a relatively undeveloped welfare state (Esping-Andersen 1999; Flaquer 2004) that makes it necessary for many couples to rely on themselves or on additional family members to care for children (Tobío 2001). Given that Spanish childcare leave policy allows access to unpaid leave through a reduction in work hours, we expect that egalitarian couples who can afford to do so will express some flexibility in men's as well as women's willingness to temporarily reduce their work hours in order to care for children. This should have a positive influence on fertility, but it presumes job stability and a feeling of economic security. Among economically secure couples who are less egalitarian, it is likely that male partners will be less willing to adjust their work schedules to devote more time to childrearing. This leads to the following expectation:

2) Among couples who do not perceive economic insecurity to be an obstacle to fertility, more gender-egalitarian couples will express greater flexibility in partners' willingness to adjust work hours to share childcare responsibilities. On balance, this should encourage higher fertility intentions. 
"This is an original manuscript / preprint of an article published by Taylor \& Francis in: Bueno, X. and Brinton, M.C. (2019): Gender egalitarianism, perceived economic insecurity, and fertility intentions in Spain: A qualitative analysis, Population Studies, 73(2): 247-260. 17 may 2019, available online: https://doi.org/10.1080/00324728.2019.1604979

After briefly summarizing recent demographic and economic trends in Spain, we turn to our interview data and findings.

\section{Demographic and economic trends in Spain}

Spain has experienced dramatic social change in the past four decades, especially in women's lives. The rate of female advancement to higher education increased from 22 to 46 percent between 1992 and 2011 for the cohort age 25-34 years (OECD Stats). While Spanish women's overall labour force participation rate remains lower than in many other European countries, the rate for younger women is comparable to other countries.

Changes in Spanish family formation patterns have also been dramatic. Within Europe, Spain has experienced one of the most rapid increases in cohabitation and in childbearing within cohabitation (Dominguez-Folgueras and Castro-Martin 2013; EspingAndersen 2013; Castro-Martín and Seiz 2014). Other changes include increased rates of separation and divorce, the spread of same-sex marriages, extensive use of contraceptive methods, and changing perceptions of single motherhood. Spain has therefore undergone many of the societal changes associated with the second demographic transition (Lesthaeghe 1995). Age at first birth has also increased substantially (from 25.2 years in 1975 to 31.5 in 2013), prompting scholars to label childbearing in Spain (together with Italy) the "latest-late" in the world (Billari and Kohler 2004).

Birth register data from 2011 indicate that highly-educated native-born women in Spain experience their first birth after age 33 on average, compared to age 28 for the leasteducated women. Highly-educated women who have a second child do so within a shorter 
"This is an original manuscript / preprint of an article published by Taylor \& Francis in: Bueno, X. and Brinton, M.C. (2019): Gender egalitarianism, perceived economic insecurity, and fertility intentions in Spain: A qualitative analysis, Population Studies, 73(2): 247-260. 17 may 2019, available online: https://doi.org/10.1080/00324728.2019.1604979

time period than women with less education; the average birth interval between first and second child was 3.5, 4.4, and 5.1 years for tertiary-, secondary-, and primary-educated women respectively during 2007-2013. In couples where both partners are universityeducated, the birth interval is even shorter (3.3 years). This is consistent with previous literature for a number of European countries (Kravdal and Rindfuss 2008; Andersson et al. 2009). Even so, average completed fertility is slightly lower for highly-educated Spanish women (1.6 children) than for women with secondary or primary education (1.7 and 1.9, respectively; Fertility and Values Survey 2006).

Turning to the economic context, Spanish unemployment rates have been high for decades even when compared to other Southern European countries. Figure 1 shows the unemployment rate for 25-34 year-olds in a number of European countries since 1970. Spain's rate was by far the highest in the 1980s and 1990s, skyrocketing once more with the European economic crisis of 2008. Figure 2 demonstrates that high unemployment extends even to young people with tertiary education. While not shown here, unemployment rates for Spanish men and women are similar, with the female rate exceeding men's in some age groups.

Figures 1, 2 about here

\section{Data and methods}

Data

We use original in-depth interviews conducted in 2012 to examine how highly-educated partnered young Spanish adults formulate their fertility ideals, intentions, and reasoning. 
"This is an original manuscript / preprint of an article published by Taylor \& Francis in: Bueno, X. and Brinton, M.C. (2019): Gender egalitarianism, perceived economic insecurity, and fertility intentions in Spain: A qualitative analysis, Population Studies, 73(2): 247-260. 17 may 2019, available online: https://doi.org/10.1080/00324728.2019.1604979

While the use of qualitative methods is less common than survey research methods in demography, structured in-depth interviews are a highly effective tool to explore how individuals express their reasoning (Randall and Koppenhaver 2004).

Our sample consists of 53 highly-educated, heterosexual, native-born, urban men and women age $24-35$ in stable cohabiting partnerships or marriage. We stratified the sample so that half of the interviewees are childless and half have one child. Equal numbers of men and women were sampled separately, so that no individuals in our data set are in unions with each other. We define higher education as the completion of tertiary education (university or post-secondary vocational school). In addition, we restrict the sample to individuals who are not full-time students, are neither pregnant nor have a pregnant partner, do not have children from a previous relationship, and who are not separated, divorced, or widowed. Samples are drawn evenly from Madrid and Barcelona, Spain's two largest urban centres.

Interviewee recruitment was done through snowball sampling, starting with a large number of individual "seeds" who each referred up to two potential interviewees. We repeated this process until all the cells in our sampling frame were filled. A disadvantage of snowball sampling is the potential existence of clusters in the final sample due to the small number of initial seeds and the limited network dispersion of referral chains. To address this concern, we performed post-hoc cluster analysis (using both single-link and median-link methods) to identify potential clusters within our sample. We based this analysis on interviewees' responses to eleven World Values Survey questions included in our interview 
"This is an original manuscript / preprint of an article published by Taylor \& Francis in: Bueno, X. and Brinton, M.C. (2019): Gender egalitarianism, perceived economic insecurity, and fertility intentions in Spain: A qualitative analysis, Population Studies, 73(2): 247-260. 17 may 2019, available online: https://doi.org/10.1080/00324728.2019.1604979

protocol. The absence of a hierarchical structure indicates that there is no clustering of particular "types" of like-minded individuals within the sample.

Both sampling and interviewing were carried out by the first author, trained as a sociologist and demographer. A strength of the study is the shared status between interviewees and interviewer (a highly-educated, native-born Spanish female in the same age range as the interviewees), which enhanced trust and made it easy to establish rapport. Interviews were conducted face-to-face in Spanish in cafes or interviewees' homes, with no family members present. The typical interview lasted 60 to 120 minutes. Interviews were voice-recorded and later transcribed in Spanish by a native speaker.

\section{Interview questions}

A structured interview protocol was used. The protocol included questions about current or most recent employment of the interviewee and his/her partner; fertility ideals, intentions, and reasoning; household division of labour and childcare; gender-role attitudes; and views on work-family policies and low-fertility policies in Spain. The interviewer also recorded biographical and financial information for each interviewee. In this paper we draw primarily on individuals' answers to questions related to the reasoning for fertility ideals and intentions and the gap between them, if any; perceived conditions or obstacles in the decision-making process; and anticipated timing for having a child.

\section{Coding process}

Coding was done in several stages. We first established structural codes to demarcate topical sections of the interview. We then inductively coded interviewees' reasons for 
"This is an original manuscript / preprint of an article published by Taylor \& Francis in: Bueno, X. and Brinton, M.C. (2019): Gender egalitarianism, perceived economic insecurity, and fertility intentions in Spain: A qualitative analysis, Population Studies, 73(2): 247-260. 17 may 2019, available online: https://doi.org/10.1080/00324728.2019.1604979

fertility ideals, intentions, and the ideals-intentions gap. Coding was done using the qualitative software Dedoose. We also wrote detailed memos describing each individual's fertility reasoning, putting it in the context of couple-level characteristics (age, education, and employment of interviewees and their partners, as well as gendered household dynamics).

Because we aim to analyse how perceived economic insecurity and gender egalitarianism influence fertility plans, we follow Kravdal (2002), Bernardi et al. (2008), and Hipp (2016) and measure individuals' subjective economic insecurity. Given our focus on the link with fertility, we code whether individuals mention economic insecurity as an obstacle to achieving their fertility ideals or to having a child (whether first or second child). If they do not, we code them as not expressing this concern. Our qualitative data provide much texture in terms of individuals' reasoning about economic insecurity as an obstacle to fertility plans or not. For example, a number of interviewees belong to couples with at least one unemployed partner. But they do not uniformly voice a sense of economic insecurity in relation to fertility plans; some of them are professionally prepared, have work experience, and feel confident in finding a job. Some also mention receiving unemployment benefits and state that their household income has barely been affected by unemployment. Under such circumstances, they may not perceive economic insecurity as an obstacle to fertility plans.

We also categorized interviewees based on their description of the gender-role dynamics with their partner. To do so, we considered how they describe dividing household labour and how they answered three additional questions. The first was how they and their 
"This is an original manuscript / preprint of an article published by Taylor \& Francis in: Bueno, X. and Brinton, M.C. (2019): Gender egalitarianism, perceived economic insecurity, and fertility intentions in Spain: A qualitative analysis, Population Studies, 73(2): 247-260. 17 may 2019, available online: https://doi.org/10.1080/00324728.2019.1604979

partner share or plan to share childcare responsibilities. Second, we considered interviewees' intention to take childcare leave at the birth of their first/second child, including their past use of leave (in the case of one-child interviewees). Finally, we considered whether they feel the mother should be the primary caregiver when a child is under three years old. Based on the consistency across these gender-role behaviours and attitudes, we categorized interviewees as being in more egalitarian or less egalitarian couples. We note in passing that none of the female interviewees expressed the desire to be stay-at-home wives and mothers, nor did any male interviewees express the desire or expectation that their partner do so. Instead, interviewees assumed that the female partner in the couple would be in the labour force. In only a few cases did interviewees anticipate that the woman would take full-time leave for one to three years or be non-employed for a short period of time. This feature of our data is consistent with the literature on Spain, contrasting sharply with East Asian low-fertility cases such as Japan (Brinton and Oh 2017), where it is more common for highly-educated women to exit the labour force for an extended number of years while childrearing.

Interviewees in the more gender-egalitarian group describe being in a couple where housework (and childcare, in the case of interviewees with one child) is more or less equally shared. They tend to express either disinterest in taking childcare leave (especially because it is unpaid) or to say that both partners are interested in reducing their working hours after childbirth. We term this "part-time leave." Members of these couples mostly disagree with the statement that a mother should focus on childcare during the first three 
"This is an original manuscript / preprint of an article published by Taylor \& Francis in: Bueno, X. and Brinton, M.C. (2019): Gender egalitarianism, perceived economic insecurity, and fertility intentions in Spain: A qualitative analysis, Population Studies, 73(2): 247-260. 17 may 2019, available online: https://doi.org/10.1080/00324728.2019.1604979

years of a child's life, with many expressing the viewpoint that both the mother and the father should do so.

Interviewees in less egalitarian couples describe a more gendered household division of labour and a heavier housework and childcare share for the female partner. In this group, men generally do not intend to take childcare leave. Their partners typically plan to take full-time leave or reduce their work hours once a child is born. These interviewees tend to favour the mother as the primary caregiver while the child is very young, contingent upon financial circumstances.

We recognize the possible limitations in our categorization of interviewees into more vs. less gender-egalitarian couples. Our interview data suggest that men may overestimate their housework contribution, an observation noted in the household division of labour literature (Kamo 2000). Among interviewees we categorize as being in less egalitarian couples, 13 are female and only 7 are male. Conversely, 19 of the interviewees we classified as being in more gender egalitarian couples are male and fewer (14) are female. This makes it all the more important to consider gender egalitarianism in couples as multidimensional, encompassing not just the household division of labour but also attitudes towards the mother as the primary caregiver and men's and women's intention to use childcare leave or cut back their working hours. Taking into account all of these factors gives us greater confidence in our categorization.

\section{Results}

Our first research question is descriptive: How much do highly-educated partnered young Spanish interviewees discuss economic insecurity as an obstacle to their fertility goals? 
"This is an original manuscript / preprint of an article published by Taylor \& Francis in: Bueno, X. and Brinton, M.C. (2019): Gender egalitarianism, perceived economic insecurity, and fertility intentions in Spain: A qualitative analysis, Population Studies, 73(2): 247-260. 17 may 2019, available online: https://doi.org/10.1080/00324728.2019.1604979

Evidence of the effect of economic insecurity on fertility reasoning is abundantly clear in our data: the majority of sampled individuals (29 out of 53) spontaneously mention it as a reason motivating their fertility plans. Childless and one-child interviewees are evenly represented in this group.

Mercedes, for example, is a 29-year-old childless female working full-time as an administrative assistant. Her partner is a 31-year-old draftsman who works full-time. Mercedes' fertility ideal is three children but she thinks she will probably have two. She states: 'Many times I have imagined myself having a family, but right now I have my feet on the ground and am feeling realistic and no, I don't presently have the chance to have a family.' When subsequently asked about the obstacles she perceives, she replies emphatically, 'Economic... employment...the economy of the country! Even though the price of housing has dropped, it is still sky-high, and employment conditions are worse.' She feels that in order to have children, the couple's employment conditions and income need to improve.

Tomás is another example. He is a 33-year-old father of one child who works parttime in a community center and whose partner (29 years old) works full-time as a preschool teacher. Their daughter is one and a half years old, and they would like to have two kids. Tomás explains that even though they were not economically stable, they didn't want to forego having children so they went ahead and had their daughter. He says, 'It is fine, but now [for the second child], well, our apartment is small...' When asked whether they intend to have a second child in the next three years, he replies: 'As of today, no. [If we 
"This is an original manuscript / preprint of an article published by Taylor \& Francis in: Bueno, X. and Brinton, M.C. (2019): Gender egalitarianism, perceived economic insecurity, and fertility intentions in Spain: A qualitative analysis, Population Studies, 73(2): 247-260. 17 may 2019, available online: https://doi.org/10.1080/00324728.2019.1604979

have a second child] we need to be able to move to a different apartment, and this is directly linked to having a higher income.'

In addition to finding much evidence of Spain's uncertain economic situation in our interviews, we also find consistency with the literature on Spain's increasingly genderegalitarian context: More interviewees $(\mathrm{N}=33)$ are in couples we characterize as genderegalitarian and fewer $(\mathrm{N}=20)$ are in couples that are less gender-egalitarian.

We turn now to our two theoretical questions concerning the intersection of gender egalitarianism and economic insecurity in relation to fertility goals. Do we see evidence that the gender egalitarianism of a couple "buffers" their perception that economic insecurity will hamper their fertility plans? And does gender egalitarianism facilitate higher fertility intentions for economically insecure and secure couples alike?

Among interviewees who do not cite economic insecurity as a concern for fertility plans $(\mathrm{N}=24)$, we indeed find that many more are in gender-egalitarian couples $(\mathrm{N}=17)$ than in less egalitarian couples ( $\mathrm{N}=7)$. Interviewees who express concern over economic insecurity, on the other hand, are equally divided between more and less gender-egalitarian couples ( $\mathrm{N}=16$ and $\mathrm{N}=13$, respectively). Thus there seems to be a lesser tendency for the more egalitarian couples in our data to express economic insecurity as a barrier to fertility goals compared to less egalitarian couples. This is what we anticipated.

As to whether egalitarianism cushions the negative effect of economic insecurity on fertility intentions, our interview data suggest a more complex answer that was presaged in our earlier discussion of what it means for couples to prioritize women's as well as men's job security. We first note that about half of our entire sample state an intention to have two 
"This is an original manuscript / preprint of an article published by Taylor \& Francis in: Bueno, X. and Brinton, M.C. (2019): Gender egalitarianism, perceived economic insecurity, and fertility intentions in Spain: A qualitative analysis, Population Studies, 73(2): 247-260. 17 may 2019, available online: https://doi.org/10.1080/00324728.2019.1604979

children; if we also include those who say "one or two" or "two or three," this becomes the majority of interviewees (40 out of 53). This is consistent with the "two-child norm" for fertility intentions in Europe (Sobotka and Beaujouan 2014). But when we divide more egalitarian interviewees into those who express economic insecurity and those who do not, we find some differences in their fertility intentions. Interviewees who perceive economic insecurity seem particularly inclined to limit their fertility intentions to "one or two" or even "one" child, while those who consider themselves economically secure are more likely to intend to have "two or three" or "three" children. This variation across egalitarian couples based on their perception of economic insecurity is striking. In contrast, the "twochild norm" is more clearly dominant among less egalitarian couples, regardless of whether or not they perceive economic insecurity. By examining the variation in fertility intentions among egalitarian couples, the complexities produced for them by Spain's dualistic labour market and modest state support for childrearing come into sharper focus.

\section{Fertility reasoning among economically insecure gender-egalitarian couples}

Nearly all interviewees in the more gender-egalitarian couples state that both partners should achieve some stability in their careers before the couple proceeds to a first birth. This contrasts with interviewees in less gender-egalitarian couples, who stress the importance of financial stability before proceeding to a first child but without necessarily mentioning women's labour market position.

Without secure jobs for both partners, many egalitarian couples seem to be engaged in a waiting game when it comes to having children. Arantxa and her partner, both 28 years 
"This is an original manuscript / preprint of an article published by Taylor \& Francis in: Bueno, X. and Brinton, M.C. (2019): Gender egalitarianism, perceived economic insecurity, and fertility intentions in Spain: A qualitative analysis, Population Studies, 73(2): 247-260. 17 may 2019, available online: https://doi.org/10.1080/00324728.2019.1604979

old, are an example. Although she trained as a nutritionist, Arantxa held a temporary job in telemarketing at the time of the interview. Her partner was an unemployed nurse. When asked about the conditions necessary to have their first child, Arantxa stressed the importance of 'having more stability. He needs a job and I need a job...,' adding 'the job I have now is not very secure.' She and her partner intend to have two children but only after securing stable jobs. Given the constraints of the Spanish labour market, Arantxa even goes so far as to say that they might leave Spain and look for jobs abroad before having children. She explains that her partner is studying English and they are aware that there is a shortage of nurses in London. 'So when he finishes his unemployment benefits...well, I have one foot in unemployment, so perhaps we will try to move to England.'

Rebeca is another example of a female interviewee in an egalitarian but economically insecure couple. Both she and her partner are currently unemployed. While Rebeca, who is 26 , would like to have two children, she thinks it is likely they will only have one because of the difficult labour market. In discussing the conditions for having their first child, she says: 'First of all... well, we need to be sure about it psychologically. But above all we need to be economically secure — to each have a good job, to have stability—both of us.'

Manuel is a 30 year old male interviewee in a gender-egalitarian partnership who also mentions economic insecurity as a possible obstacle to having children. He has considerable stability in his research job but his partner, who is 29 , is in a temporary job with which she feels dissatisfied. Manuel says that he personally feels ready to have a child but they are waiting until his partner feels more secure in the labour market. Although he 
"This is an original manuscript / preprint of an article published by Taylor \& Francis in: Bueno, X. and Brinton, M.C. (2019): Gender egalitarianism, perceived economic insecurity, and fertility intentions in Spain: A qualitative analysis, Population Studies, 73(2): 247-260. 17 may 2019, available online: https://doi.org/10.1080/00324728.2019.1604979

would like to have three or four children, he thinks it more likely that they will have two. As he states: 'In our case, the most important thing is whether my partner wants to move forward to have a child. I have told her that whenever she wants, whenever she feels ready and considers it to be the right moment, let's go ahead. I think we can afford it now, but it will depend on when she feels fulfilled in other aspects. She wants to wait.'

Manuel's case raises the issue of whether female partners' desire to become established in the labour market is purely based on an economic rationale or also includes other motivations. In the context of a society where gender egalitarianism is more and more the norm, the female interviewees in many of the more egalitarian couples mention motivations such as autonomy and fulfilment that go beyond the economic. These suggest that being a dual-earner couple in the Spanish context has an ideological as well as an economic rationale. Likewise, the male interviewees in many egalitarian couples express recognition of such desires on the part of their partner.

The three cases mentioned so far-Arantxa, Rebeca, and Manuel—all represent interviewees in egalitarian couples who perceive economic insecurity as an obstacle to fertility plans. All are childless so far. Their reasoning about fertility encompasses wanting both partners to become established in the labour market before proceeding to parenthood. In fact, the large majority of economically insecure egalitarian interviewees were childless at the time of the interview. 
"This is an original manuscript / preprint of an article published by Taylor \& Francis in: Bueno, X. and Brinton, M.C. (2019): Gender egalitarianism, perceived economic insecurity, and fertility intentions in Spain: A qualitative analysis, Population Studies, 73(2): 247-260. 17 may 2019, available online: https://doi.org/10.1080/00324728.2019.1604979

\section{Fertility reasoning among economically secure egalitarian couples}

Economically secure egalitarian interviewees were evenly divided between the childless and those with one child. Among those who already had a child, another aspect of the Spanish context comes into play: the difficulty of achieving work-life balance, especially given that public childcare spaces are limited, private childcare is expensive, and Spanish childcare leave is unpaid. Many interviewees see a reduction in work hours on both the mother's and father's part as highly desirable when children are young. But the value they place on both members of the couple remaining employed translates into a daily time squeeze and the feeling that additional help in housework and/or childcare is necessary. Pablo exemplifies interviewees who stress the difficulties of work-life balance as the main reason for delaying the transition to a second child. Both he and his partner reduced their working hours substantially during the first year after their daughter was born. Pablo is a 33 years old self-employed and works from home. He does more housework and childcare than his partner, who is the higher earner in the couple and she is 31 . He describes the time required by childrearing as follows: 'Our daughter is two years old and needs us constantly. She is not independent in any respect, and we would not be able to find time to take care of another child in the same way we have taken care of her. No, literally it cannot fit into our schedule...within the 24 hours of a day, another baby or small child would not fit. Now we understand what this means. Before, it was very abstract, but now it is very concrete' [laughter].

Many interviewees in egalitarian couples who do not perceive economic insecurity strive to achieve work-family balance by outsourcing some housework, especially the more 
"This is an original manuscript / preprint of an article published by Taylor \& Francis in: Bueno, X. and Brinton, M.C. (2019): Gender egalitarianism, perceived economic insecurity, and fertility intentions in Spain: A qualitative analysis, Population Studies, 73(2): 247-260. 17 may 2019, available online: https://doi.org/10.1080/00324728.2019.1604979

arduous tasks such as house cleaning. Interviewees' narratives suggest that by doing this, the couple experiences less conflict and can more easily achieve an equilibrium for other tasks that need to be done. Some interviewees say that by outsourcing housework they can maximize the time spent with their partner and family. Childcare strategies among interviewees in the most egalitarian couples are diverse. In some cases both partners plan to reduce their working hours, while in others both plan to continue working full-time but to adjust their schedules. A number of male interviewees state that their partner will reduce her working hours and that they themselves have a flexible work schedule and will not need to reduce their own work hours. (This may or may not be accurate, as few female interviewees mentioned work flexibility on the part of their partners.)

In sum, our interviewees' fertility planning seems to be facilitated or hindered by their egalitarianism depending on their level of perceived economic insecurity. The first expectation we outlined - that the positive influence of gender-role egalitarianism on fertility plans will prevail even when individuals feel economically insecure - is thus not borne out. Instead, egalitarian couples' prioritization of a stable job for both men and women—a scarce commodity in Spain's insider-outsider labour market—appears to lead many such couples who are economically insecure to hesitate moving forward with their fertility plans. Another of our expectations was that once both partners in more egalitarian couples are stably employed, their egalitarianism leads them to both be willing to reduce their work hours in order to participate in childrearing. Manuel and a number of others in our data provide support for this expectation. But whether or not their fertility intentions are positively affected seems to be an open question. Why? Having fought and won the 
"This is an original manuscript / preprint of an article published by Taylor \& Francis in: Bueno, X. and Brinton, M.C. (2019): Gender egalitarianism, perceived economic insecurity, and fertility intentions in Spain: A qualitative analysis, Population Studies, 73(2): 247-260. 17 may 2019, available online: https://doi.org/10.1080/00324728.2019.1604979

difficult battle of securing stable jobs in Spain's bifurcated labour market, highly

egalitarian couples face a second battle: the one posed by an inadequate parental leave system and a shortage of public childcare. Unpaid leave is available but obviously leads to short-term loss of income, and thus needs to be utilized judiciously. In exacerbating the time squeeze highly egalitarian couples feel between employment and childrearing, it can lead couples to express hesitation about having another child. This is brought into sharper relief when we contrast it with the counter-example of less egalitarian couples.

\section{Fertility reasoning among less gender-egalitarian couples}

Compared to the more egalitarian interviewees in our sample, the fertility intentions of interviewees in less egalitarian couples vary little according to the perception of economic insecurity or not. Most intend to have two children, and some intend to have "two or three."

Abril is a female interviewee in a less egalitarian couple with one child. She is 27 years old, unemployed, and does most of the housework and childcare. Abril perceives economic insecurity as a fertility obstacle but nevertheless has the intention to have two children. A key difference between Abril on the one hand and interviewees in economically insecure but more egalitarian couples is that Abril is less concerned about having a stable full-time job. She states that she currently does not feel pressure to actively look for a job. When asked whether she would like to be a stay-at-home mother Abril rejects the idea, saying 'I don't want to be a "trophy wife."' But on the other hand, she is not seriously thinking of working full-time. As she puts it, 'I would like to work, but also to stay with my daughter.' When the interviewer follows up by asking 'If you had a job, what kind of job 
"This is an original manuscript / preprint of an article published by Taylor \& Francis in: Bueno, X. and Brinton, M.C. (2019): Gender egalitarianism, perceived economic insecurity, and fertility intentions in Spain: A qualitative analysis, Population Studies, 73(2): 247-260. 17 may 2019, available online: https://doi.org/10.1080/00324728.2019.1604979

would it be?' Abril replies, 'A part-time job, so that I could spend part-time at home and part-time outside the home.' Abril's case illustrates that in contrast to more egalitarian interviewees, those in less-egalitarian couples are more apt to assume that the mother will adapt her work life while the father continues working full-time. Women in less gender egalitarian couples also generally say they cannot expect their partner to reduce his working hours (i.e. take part-time unpaid leave) after becoming a parent. In a sense, these couples in our highly-educated urban sample come the closest to fitting the male-breadwinner model.

\section{Conclusion}

This paper has examined how the interaction between couples' gender egalitarianism and perceived economic insecurity influences the family formation plans of young highlyeducated partnered adults in urban Spain. In doing so, we aim to make a theoretical contribution by bringing together two substantial literatures in low-fertility research: gender equity theory and the empirical literature on economic insecurity. We also bring to bear the strengths of qualitative research in accessing individuals' explanation of the reasoning they use to make decisions and the conditions they consider as important (DiMaggio 2014).

Consistent with the literature on Spanish fertility, the majority of interviewees in our sample raise economic insecurity as an obstacle to their fertility plans. The majority of interviewees also fit our characterization of being quite gender egalitarian in their attitudes and behaviours. But these two dimensions interact in complex ways to influence fertility plans. More gender-egalitarian interviewees express interest in both members of the couple being stably employed in order to plan for children; when they do have such economic 
"This is an original manuscript / preprint of an article published by Taylor \& Francis in: Bueno, X. and Brinton, M.C. (2019): Gender egalitarianism, perceived economic insecurity, and fertility intentions in Spain: A qualitative analysis, Population Studies, 73(2): 247-260. 17 may 2019, available online: https://doi.org/10.1080/00324728.2019.1604979

security, such interviewees appear more likely to state an intention for two or even three children than gender-egalitarian interviewees who perceive economic instability. However, in order for gender egalitarianism to "fulfil its promise" of increasing fertility, our interview data suggest that institutional support is important. Our findings are consistent with McDonald's emphasis on the importance of gender egalitarianism within couples as well as an institutional environment that supports dual-earner couples. Our qualitative data illustrate how Spain falls short in the institutional domain, as stably-employed dual-earner egalitarian couples wrestle with decisions about unpaid childcare leave and about balancing the dual commodities of income and time.

On the other hand, the fertility intentions of interviewees in less egalitarian couples are somewhat more centred on the two-child norm common across Europe (Sobotka and Beaujouan 2014). With less concern for the female partner's stable employment, such couples seem less likely to limit their intentions to "one or two" children but also less likely to stretch to an intention of "two or three." The overall level of gender egalitarianism in Spain and the climate of economic uncertainty mean that women's employment is valued even among these couples, but at the same time they are more likely to assume women's availability to be full-time or near-full-time caregivers when children are under three years old.

While in-depth interviews provide a window into individuals' reasoning that quantitative data cannot, there are also important limitations of our analysis. Obviously our sample size is too small to either permit generalization or to go beyond suggesting the complexity of the relationships between gender egalitarianism, economic insecurity, and 
"This is an original manuscript / preprint of an article published by Taylor \& Francis in: Bueno, X. and Brinton, M.C. (2019): Gender egalitarianism, perceived economic insecurity, and fertility intentions in Spain: A qualitative analysis, Population Studies, 73(2): 247-260. 17 may 2019, available online: https://doi.org/10.1080/00324728.2019.1604979

fertility. Rather, we hope to stimulate future research by raising issues that have neither been fully theorized nor empirically tested. Our interviews provide suggestive evidence for the positive influence on young highly-educated adults' fertility plans of gender egalitarianism and institutional support for dual-earner couples, and also demonstrate the constraining influence of insider-outsider labour markets such as Spain's.

Acknowledgements: This work was supported by the European Union's Horizon 2020 research and innovation programme under the Marie Skłodowska-Curie Grant Agreement No. 657030 to Xiana Bueno and by National Science Foundation grant \#SES1123885 to Mary C. Brinton. 
"This is an original manuscript / preprint of an article published by Taylor \& Francis in: Bueno, X. and Brinton, M.C. (2019): Gender egalitarianism, perceived economic insecurity, and fertility intentions in Spain: A qualitative analysis, Population Studies, 73(2): 247-260. 17 may 2019, available online: https://doi.org/10.1080/00324728.2019.1604979

\section{Bibliography}

Adserà, Alicia. 2004. Changing Fertility Rates in Developed Countries: The Impact of Labour Market Institutions, Journal of Population Economics 17 (1): 17-43.

Adserà, Alicia. 2006. An Economic Analysis of the Gap between Desired and Actual Fertility: The Case of Spain, Review of Economics of the Household 4 (1): 75-95.

Adserà, Alicia. 2011a. The Interplay of Employment Insecurity and Education in Explaining Second Births in Europe, Demographic Research S12 (16): 513-44.

Adserà, Alicia. 2011b. Where Are the Babies? Labour Market Conditions and Fertility in Europe, European Journal of Population 27 (1): 1-32.

Ahn, Namkee, and Pedro Mira. 2001. Job bust, baby bust? Evidence from Spain, Journal of Population Economics 14 (3): 505-521.

Andersson, Gunnar. 2008. A Review of Policies and Practices Related to the 'HighestLow' Fertility of Sweden, Vienna Yearbook of Population Research 6: 89-102.

Andersson, G., Marit Rønsen, Lisbeth B. Knudsen, Trude Lappegård, Gerda Neyer, Kari Skrede, Kathrin Teschner, and Andres Vikat. 2009. Cohort Fertility Patterns in the Nordic Countries, Demographic Research 20 (14): 313-52.

Arpino, Bruno and Lara P. Tavares. 2013. Fertility and Values in Italy and Spain: A Look at Regional Differences within the European Context, Population Review 52 (1): 62-86. Arpino, Bruno, Gøsta Esping-Andersen and Léa Pessin. 2015. How Do Changes in Gender Role Attitudes Towards Female Employment Influence Fertility? A Macro-Level Analysis, European Sociological Review 31 (3): 370-382. 
"This is an original manuscript / preprint of an article published by Taylor \& Francis in: Bueno, X. and Brinton, M.C. (2019): Gender egalitarianism, perceived economic insecurity, and fertility intentions in Spain: A qualitative analysis, Population Studies, 73(2): 247-260. 17 may 2019, available online: https://doi.org/10.1080/00324728.2019.1604979

Baizán, Pau. 2009. Regional Child Care Availability and Fertility Decisions in Spain, Demographic Research 21 (27): 803-42.

Bernardi, Laura, Andreas Klärner, and Holger von der Lippe. 2008. Job Insecurity and the Timing of Parenthood: A Comparison between Eastern and Western Germany, European Journal of Population 24 (3): 287-313.

Bernhardt, Eva, and Frances Goldscheider. 2006. Gender Equality, Parenthood Attitudes, and First Births in Sweden, Vienna Yearbook of Population Research 4: 19-39.

Billari, Francesco, and Hans-Peter Kohler. 2004. Patterns of Low and Lowest-Low Fertility in Europe, Population Studies 58 (2): 161-76.

Brinton, Mary C., and Dong-Ju Lee. 2016. Gender-Role Ideology, Labour Market Institutions, and Post-industrial Fertility, Population and Development Review 42 (3): 405-433.

Brinton, Mary C., and Eun Sil Oh. 2017. Babies, Work, or Both? The Interdependence of Women's Employment and Fertility in East Asia. Paper presented at the Annual Meetings of the American Sociological Association, Montreal, August 2017.

Brinton, Mary C., Xiana Bueno, Liva S. Olah, and Merete Hellum. Forthcoming. Postindustrial Fertility Ideals, Intentions, and Gender Inequality: A Comparative Qualitative Analysis, Population and Development Review (June 2018, forthcoming)

Castro-Martín, Teresa, and Teresa Martín-García. 2013. The Fertility Gap in Spain: Late Parenthood, Few Children, and Unfulfilled Reproductive Desires, in Gøsta EspingAndersen (Ed.), The Fertility Gap in Europe: Singularities for the Spanish Case. Estudis Socials, vol. 36. Barcelona: Obra Social Fundación "La Caixa”, pp. 45-81. 
"This is an original manuscript / preprint of an article published by Taylor \& Francis in: Bueno, X. and Brinton, M.C. (2019): Gender egalitarianism, perceived economic insecurity, and fertility intentions in Spain: A qualitative analysis, Population Studies, 73(2): 247-260. 17 may 2019, available online: https://doi.org/10.1080/00324728.2019.1604979

Castro-Martín, Teresa, and Marta Seiz-Puyuelo. 2014. La transformación de las familias en España desde una perspectiva socio-demográfica [The Transformation of Families in Spain from a Socio-demographic Perspective.] Madrid: Fundación FOESSA.

Cooke, Lynn Prince. 2004. The Gendered Division of Labour and Family Outcomes in Germany, Journal of Marriage and Family 66 (5): 1243-1256.

Cooke, Lynn Prince. 2009. Gender Equity and Fertility in Italy and Spain, Journal of Social Policy 38 (1): 123-140.

De la Rica, Sara, and Amaia Iza. 2005. Career Planning in Spain: Do Fixed-Term Contracts Delay Marriage and Parenthood?, Review of Economics of the Household 3 (1): 49-73.

DiMaggio, Paul. 2014. Comment on Jerolmack and Khan, 'Talk is Cheap': Ethnography and the Attitudinal Fallacy, Sociological Methods and Research 43 (2): 232-235.

Dominguez-Folgueras, Marta, and Teresa Castro-Martin. 2013. Cohabitation in Spain: No Longer a Marginal Path to Family Formation, Journal of Marriage and Family 75 (2): $422-37$.

Esping-Andersen, Gøsta. 1999. Social Foundations of Post-industrial Economies. New York: Oxford University Press.

Esping-Andersen, Gøsta. (Ed.). 2013. The Fertility Gap in Europe: Singularities of the Spanish Case. Estudios Socials, vol. 36. Barcelona: Obra Social Fundación "La Caixa." Esping-Andersen, Gøsta, and Francesco C. Billari. 2015. Re-Theorizing Family Demographics, Population and Development Review 41 (1): 1-31. 
"This is an original manuscript / preprint of an article published by Taylor \& Francis in: Bueno, X. and Brinton, M.C. (2019): Gender egalitarianism, perceived economic insecurity, and fertility intentions in Spain: A qualitative analysis, Population Studies, 73(2): 247-260. 17 may 2019, available online: https://doi.org/10.1080/00324728.2019.1604979

Flaquer, Lluis. 2004. La articulación entre familia y el Estado de bienestar en los países del Sur de Europa [The Articulation between Family and the Welfare State in the Countries of Southern Europe], Papers: Revista de Sociología 73: 27-58.

Goldscheider, Frances, Eva Bernhardt, and Trude Lappegård. 2015. The Gender

Revolution: A Framework for Understanding Changing Family and Demographic

Behavior, Population and Development Review 41 (2): 207-39.

Goldstein, Joshua R., Tomáš Sobotka, and Aiva Jasilioniene. 2009. The End of "LowestLow" Fertility?, Population and Development Review 35 (4): 663-699.

Harknett, Kristen, and Caroline Sten Hartnett. 2014. The Gap Between Births Intended and Births Achieved in 22 European Countries, 2004-07, Population Studies 68(3): 265-282.

Hipp, Lena. 2016. Insecure Times? Workers' Perceived Job and Labor Market Security in 23 OECD Countries, Social Science Research 60 (C): 1-14.

Kamo, Yoshinori. 2000. 'He Said, She Said': Assessing Discrepancies in Husbands' and Wives' Reports on the Division of Household Labor, Social Science Research 29 (4): 459-476.

Knight, Carly R., and Mary C. Brinton. 2017. One Egalitarianism or Several? Two Decades of Gender-Role Attitude Change in Europe, American Journal of Sociology 123 (4): $1485-1532$.

Kohler, Hans-Peter, Francesco Billari, and José Antonio Ortega. 2002. The Emergence of Lowest-Low Fertility in Europe During the 1990s, Population and Development Review 28 (4): 641-680. 
"This is an original manuscript / preprint of an article published by Taylor \& Francis in: Bueno, X. and Brinton, M.C. (2019): Gender egalitarianism, perceived economic insecurity, and fertility intentions in Spain: A qualitative analysis, Population Studies, 73(2): 247-260. 17 may 2019, available online: https://doi.org/10.1080/00324728.2019.1604979

Kravdal, Øystein. 2002. The Impact of Individual and Aggregate Unemployment on Fertility in Norway, Demographic Research 6 (10): 263-94.

Kravdal, Øystein, and Ronald R. Rindfuss. 2008. Changing Relationships between Education and Fertility: A Study of Women and Men Born 1940 to 1964, American Sociological Review 73 (5): 854-73.

Kreyenfeld, Michaela. 2010. Uncertainties in Female Employment Careers and the Postponement of Parenthood in Germany, European Sociological Review 26 (3): 35166.

Kreyenfeld, Michaela, Gunnar Andersson, and Ariane Pailhé. 2012. Economic Uncertainty and Family Dynamics in Europe: Introduction, Demographic Research S12 (28): 83552.

Lapuerta, Irene, Pau Baizán and María José González. 2011. Individual and Institutional Constraints: An Analysis of Parental Leave Use and Duration in Spain, Population Research and Policy Review 30 (2): 185-210.

Lesthaeghe, Ron. 1995. The Second Demographic Transition in Western countries: An Interpretation, in Karen Oppenheim Mason and Ann-Magritt Jensen, (Eds.), Gender and Family Change in Industrialized Countries. Oxford: Clarendon, pp. 17-62.

McDonald, Peter. 2000. Gender Equity in Theories of Fertility Transition, Population and Development Review 26 (3): 427-439.

McDonald, Peter. 2006. Low Fertility and the State: The Efficacy of Policy, Population and Development Review 32 (3): 485-510. 
"This is an original manuscript / preprint of an article published by Taylor \& Francis in: Bueno, X. and Brinton, M.C. (2019): Gender egalitarianism, perceived economic insecurity, and fertility intentions in Spain: A qualitative analysis, Population Studies, 73(2): 247-260. 17 may 2019, available online: https://doi.org/10.1080/00324728.2019.1604979

McDonald, Peter. 2013. Societal Foundations for Explaining Fertility: Gender Equity, Demographic Research 28 (34): 981-94.

Meil, Gerardo, Cristina García Saínz, María Ángeles Luque and Luis Ayuso. 2008. Las grandes empresas y la conciliación de la vida laboral y personal en España [Large Companies and the Reconciliation of Work and Family Life in Spain], Revista del Ministerio de Trabajo e Inmigración, 71: 15-33.

Mills, Melinda. 2010. Gender Roles, Gender (In)equality and Fertility: An Empirical Test of Five Gender Equity Indices, Canadian Studies in Population 37 (3-4): 445-474.

Mills, Melinda, Hans-Peter Blossfeld, and Erik Klijzing. 2005. Becoming an Adult in Insecure Times: A 14-Country Comparison of the Losers of Globalization, in Hans-Peter Blossfeld, Erik Klijzing, Melinda Mills, and Karen Kurz (Eds.), Globalization, Insecurity and Youth in Society. London/New York: Routledge Advances in Sociology Series, pp. 423-441.

Nagase, Nobuko, and Mary C. Brinton. 2017. The Gender Division of Labor and Second Births: Labor Market Institutions and Fertility in Japan, Demographic Research 36: 339-370.

OECD Stats. (www.stats.oecd.org).

Oláh, Livia Sz. 2003. Gendering Fertility: Second Births in Sweden and Hungary, Population Research and Policy Review 22: 171-200.

Örsal, Deniz Dilan Karaman, and Joshua R. Goldstein. 2018. The Changing Relationship between Unemployment and Total Fertility, Population Studies 72: 1-13. 
"This is an original manuscript / preprint of an article published by Taylor \& Francis in: Bueno, X. and Brinton, M.C. (2019): Gender egalitarianism, perceived economic insecurity, and fertility intentions in Spain: A qualitative analysis, Population Studies, 73(2): 247-260. 17 may 2019, available online: https://doi.org/10.1080/00324728.2019.1604979

Özcan, Berkay, Karl Ulrich Mayer, and Joerg Luedicke. 2010. The Impact of

Unemployment on the Transition to Parenthood, Demographic Research S12 (29): 80746.

Puur, Allan, Livia Sz. Oláh, Mariam Irene Tazi-Preve, and Jürgen Dorbritz. 2008. Men’s Childbearing Desires and Views of the Male Role in Europe at the Dawn of the 21st Century, Demographic Research 19 (56): 1883-1912.

Randall, Sara, and Todd Koppenhaver. 2004. Qualitative Data in Demography: The Sound of

Silence and Other Problems, Demographic Research 11 (3): 57-93.

Raymo, James M., and Akihisa Shibata. 2017. Unemployment, Nonstandard Employment, and Fertility: Insights from Japan's 'Lost 20 Years,' Demography 54 (6): 2301-2330.

Rondinelli, Concetta, Arnstein Aassve, and Francesco Billari. 2010. Women`s Wages and Childbearing Decisions: Evidence from Italy, Demographic Research S12 (19): 549-78.

Schmitt, Christian. 2008. Gender-Specific Effects of Unemployment on Family Formation: A Cross-National Perspective, Discussion papers 841, German Institute for Economic Research (Berlin).

Simó Noguera, Carles, Katrin Golsch, and Nikolei Steinhage. 2002. Increasing Uncertainty in the Spanish Labor Market and Entry into Parenthood. Genus, 58 (1): 77-119.

Sobotka, Tomáš, and Éva Beaujouan. 2014. Two Is Best? The Persistence of a Two-Child Family Ideal in Europe, Population and Development Review 40 (3): 391-419.

Sobotka, Tomáš, Vegard Skirbekk, and Dimiter Philipov. 2011. Economic Recession and Fertility in the Developed World, Population and Development Review 37 (2): 267-306. 
"This is an original manuscript / preprint of an article published by Taylor \& Francis in: Bueno, X. and Brinton, M.C. (2019): Gender egalitarianism, perceived economic insecurity, and fertility intentions in Spain: A qualitative analysis, Population Studies, 73(2): 247-260. 17 may 2019, available online: https://doi.org/10.1080/00324728.2019.1604979

Sullivan, Oriel, Francesco C. Billari, and Evrim Altintas. 2014. Fathers' Changing

Contributions to Child Care and Domestic Work in Very Low-Fertility Countries: The Effect of Education, Journal of Family Issues 35 (8): 1048-1065.

Testa, María Rita, and Stuart Gietel-Basten. 2014. Certainty of Meeting Fertility Intentions: Declines in Europe During the 'Great Recession,' Demographic Research 31 (23): 687734.

Tobío, C. 2001. Working and Mothering: Women's Strategies in Spain. European Societies 3 (3): 339-371.

Tölke, Angelika, and Martin Diewald. 2003. Insecurities in Employment and Occupational Careers and Their Impact on the Transition to Fatherhood in Western Germany, Demographic Research 9 (3): 41-68.

Torr, Berna Miller, and Susan E. Short. 2004. Second Births and the Second Shift: A Research Note on Gender Equity and Fertility, Population and Development Review 30 (1): 109-130.

Vignoli, Daniele, Sven Drefahl, and Gustavo De Santis. 2012. Whose Job Instability Affects the Likelihood of Becoming a Parent in Italy? A Tale of Two Partners, Demographic Research S12 (2): 41-62. 
"This is an original manuscript / preprint of an article published by Taylor \& Francis in: Bueno, X. and Brinton, M.C. (2019): Gender egalitarianism, perceived economic insecurity, and fertility intentions in Spain: A qualitative analysis, Population Studies, 73(2): 247-260. 17 may 2019, available online: https://doi.org/10.1080/00324728.2019.1604979

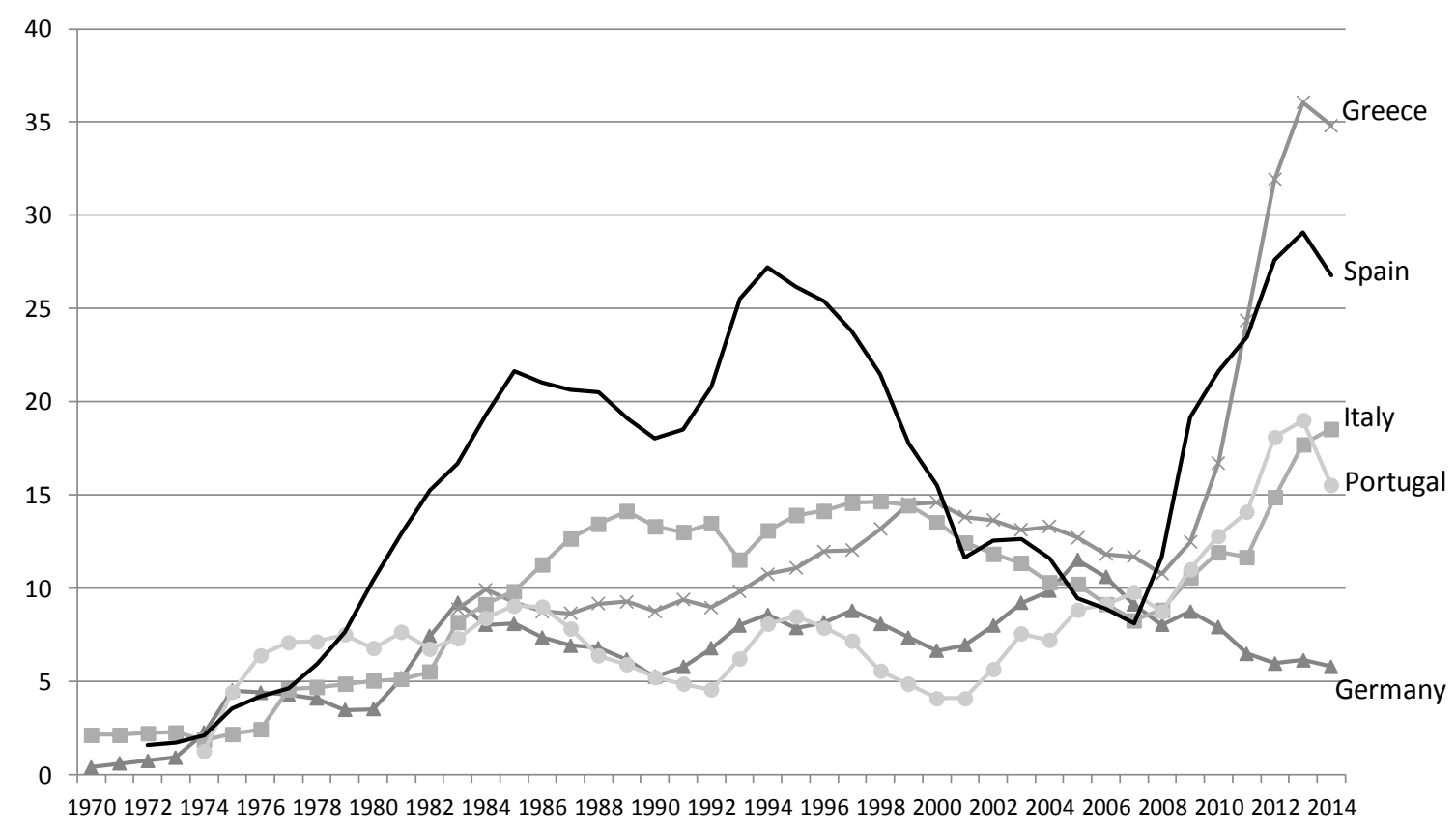

Figure 1. Unemployment rate for 25-34-year olds, 1970-2014: Selected OECD countries Source: OECD Stats (www.stats.oecd.org). 
"This is an original manuscript / preprint of an article published by Taylor \& Francis in: Bueno, X. and Brinton, M.C. (2019): Gender egalitarianism, perceived economic insecurity, and fertility intentions in Spain: A qualitative analysis, Population Studies, 73(2): 247-260. 17 may 2019, available online: https://doi.org/10.1080/00324728.2019.1604979

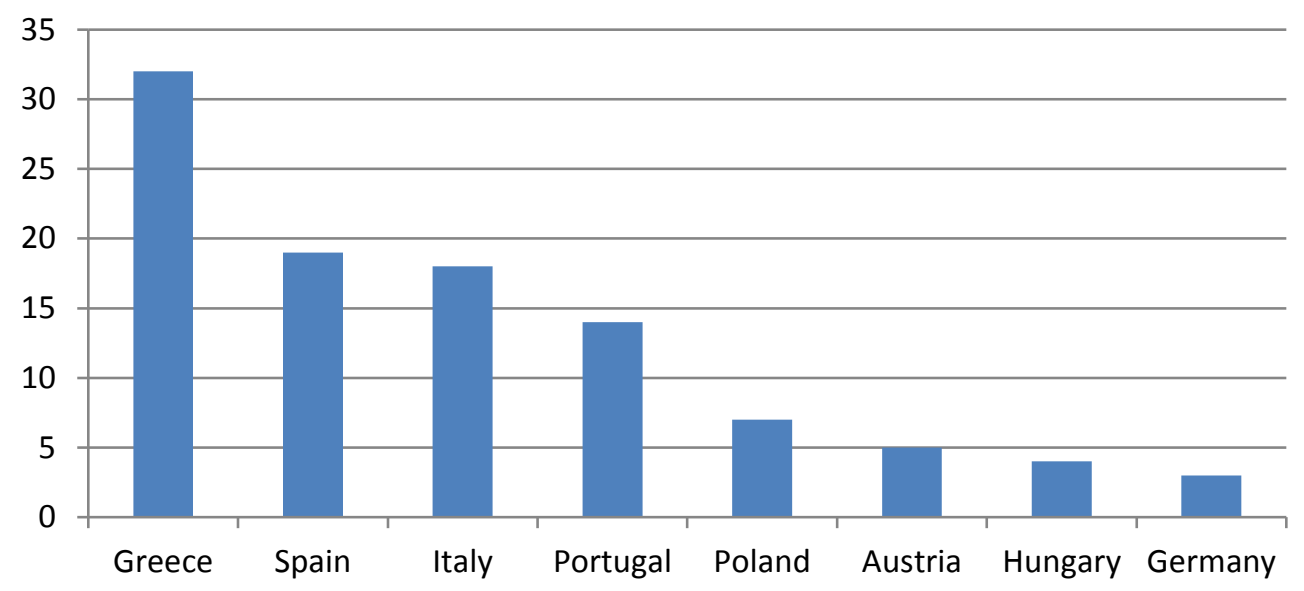

Figure 2. Unemployment rate for 25-34 year olds with tertiary education (2014): Selected OECD countries

Source: OECD Stats (www.stats.oecd.org). 
"This is an original manuscript / preprint of an article published by Taylor \& Francis in: Bueno, X. and Brinton, M.C. (2019): Gender egalitarianism, perceived economic insecurity, and fertility intentions in Spain: A qualitative analysis, Population Studies, 73(2): $247-260$. 17 may 2019, available online: https://doi.org/10.1080/00324728.2019.1604979

Appendix. Interviewee Characteristics

\begin{tabular}{|c|c|c|c|c|c|c|c|c|}
\hline ID & Sex & $\begin{array}{l}\text { Age (male } \\
\text { partner/ } \\
\text { female } \\
\text { partner) }\end{array}$ & $\begin{array}{l}\text { Family } \\
\text { formation } \\
\text { stage }\end{array}$ & $\begin{array}{l}\text { Gender } \\
\text { egalitarian } \\
\text { category }\end{array}$ & $\begin{array}{l}\text { Ideal } \\
\text { fertility }\end{array}$ & $\begin{array}{l}\text { Intended } \\
\text { fertility }\end{array}$ & Couple's economic arrangement & $\begin{array}{l}\text { Net household } \\
\text { income } \\
\text { (Euros/month) }\end{array}$ \\
\hline \multicolumn{9}{|c|}{ Couples who perceive economic insecurity as an obstacle for fertility } \\
\hline Arantxa & $\mathrm{F}$ & $28 / 28$ & Childless & More egalitarian & 2 & 2 & Male unemployed & 1685 \\
\hline Belén & $\mathrm{F}$ & $29 / 26$ & Childless & More egalitarian & 3 & 3 & Dual-earner (equal earners) & 3000 \\
\hline Diego & $\mathrm{M}$ & $28 / 29$ & Childless & More egalitarian & 2 & 2 & Dual-earner (male higher earner) & 2667 \\
\hline Eduardo & $\mathrm{M}$ & $24 / 25$ & Childless & More egalitarian & No ideal & $1-2$ & Dual-earner (female higher earner) & 1780 \\
\hline Elsa & $\mathrm{F}$ & $33 / 35$ & One-child & More egalitarian & 2 & 2 & Male unemployed & 1560 \\
\hline Eulalia & $\mathrm{F}$ & $32 / 33$ & Childless & More egalitarian & 3 & $2-3$ & Dual-earner (unknown salaries) & Missing \\
\hline Federico & $\mathrm{M}$ & $26 / 30$ & Childless & More egalitarian & 3 & $1-2$ & Female unemployed & 2600 \\
\hline Javier & $\mathrm{M}$ & $26 / 26$ & Childless & More egalitarian & 3 & 2 & Dual-earner (equal earners) & 2750 \\
\hline Julián & $\mathrm{M}$ & $33 / 34$ & Childless & More egalitarian & No ideal & 2 & Female unemployed & 1600 \\
\hline Manuel & $\mathrm{M}$ & $30 / 29$ & Childless & More egalitarian & $3-4$ & 2 & Dual-earner (male higher earner) & 1833 \\
\hline Paula & $\mathrm{F}$ & $30 / 28$ & Childless & More egalitarian & 2 & 2 & Male unemployed & 1900 \\
\hline Pedro & $\mathrm{M}$ & $34 / 36$ & One-child & More egalitarian & 2 & 1 & Dual-earner (male higher earner) & 3000 \\
\hline Rebeca & $\mathrm{F}$ & $25 / 26$ & Childless & More egalitarian & 2 & 1 & Both unemployed & 1183 \\
\hline Teresa & $\mathrm{F}$ & $30 / 30$ & One-child & More egalitarian & $3-4$ & $3-4$ & Dual-earner (male higher earner) & 2700 \\
\hline Tomás & $\mathrm{M}$ & $33 / 29$ & One-child & More egalitarian & 2 & 2 & Dual-earner (equal earners) & 2200 \\
\hline Victor & $\mathrm{M}$ & $32 / 28$ & Childless & More egalitarian & 2 & 1 & Male unemployed & 2500 \\
\hline Abril & $\mathrm{F}$ & $31 / 27$ & One-child & Less egalitarian & 2 & 2 & Female unemployed & 1920 \\
\hline Ainhoa & $\mathrm{F}$ & $31 / 33$ & Childless & Less egalitarian & $3-4$ & 2 & Dual-earner (female higher earner) & 7500 \\
\hline Clara & $\mathrm{F}$ & $25 / 24$ & One-child & Less egalitarian & 3 & 2 & Dual-earner (unknown salaries) & Missing \\
\hline Daniela & $\mathrm{F}$ & $30 / 31$ & Childless & Less egalitarian & 2 & 2 & Female unemployed & Missing \\
\hline Elisa & $\mathrm{F}$ & $31 / 28$ & One-child & Less egalitarian & 3 & $2-3$ & Female unemployed & 1500 \\
\hline Margarita & $\mathrm{F}$ & $34 / 33$ & One-child & Less egalitarian & $2-3$ & 2 & Dual-earner (male higher earner) & Missing \\
\hline
\end{tabular}


"This is an original manuscript / preprint of an article published by Taylor \& Francis in: Bueno, X. and Brinton, M.C. (2019): Gender egalitarianism, perceived economic insecurity, and fertility intentions in Spain: A qualitative analysis, Population Studies, 73(2): $247-260$. 17 may 2019, available online: https://doi.org/10.1080/00324728.2019.1604979

\begin{tabular}{|l|l|l|l|l|l|l|l|l|} 
Mercedes & $\mathrm{F}$ & $31 / 29$ & Childless & Less egalitarian & 3 & 2 & Dual-earner (unknown salaries) & Missing \\
\hline Pamela & $\mathrm{F}$ & $38 / 27$ & Childless & Less egalitarian & 2 & 1 & Dual-earner (male higher earner) & Missing \\
\hline Ruth & $\mathrm{F}$ & $28 / 26$ & Childless & Less egalitarian & 2 & 2 & Dual-earner (equal earners) & 2000 \\
\hline Alejandro & $\mathrm{M}$ & $29 / 30$ & Childless & Less egalitarian & 3 & $2-3$ & Female unemployed & 2560 \\
\hline Cristian & $\mathrm{M}$ & $33 / 31$ & One-child & Less egalitarian & $2-3$ & 2 & Dual-earner (unknown salaries) & Missing \\
\hline Ignacio & $\mathrm{M}$ & $25 / 25$ & Childless & Less egalitarian & Insecure & Insecure & Dual-earner (female higher earner) & 1650 \\
\hline Jacobo & $\mathrm{M}$ & $29 / 35$ & One-child & Less egalitarian & $2-3$ & $2-3$ & Dual-earner (equal earners) & 1000 \\
\hline
\end{tabular}

Couples who do not perceive economic insecurity as an obstacle for fertility

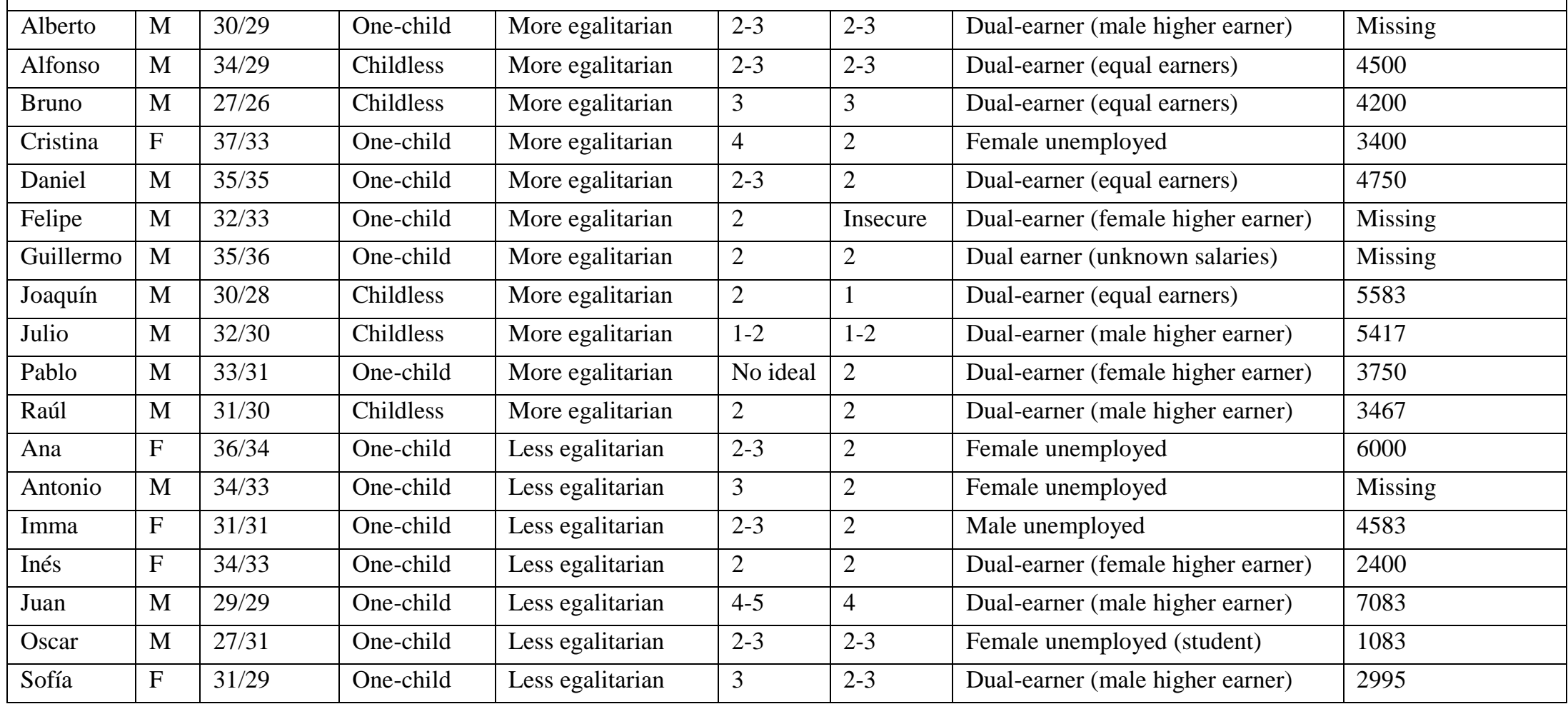

